\title{
ENGAGING STUDENTS THROUGHEVENT MARKETING: AN EXAMPLE OF UNIVERSITY ENTREPRENEURSHIP EVENT
}

\author{
Alev KOÇAK ALAN ${ }^{1}$ \\ Ebru TÜMER KABADAYI ${ }^{2}$ \\ Cansu GÖKMEN KÖKSAL ${ }^{3}$
}

\author{
Received (Başvuru Tarihi): 07/08/2017 \\ Accepted (Kabul Tarihi): 24/10/2017 \\ Published Date (Yayin Tarihi): 20/12/2017
}

\begin{abstract}
Based on the growing importance of event marketing, this study investigates the impact of entrepreneurship event on university students which was hosted by one of the leading universities in Turkey. In this context, three different aspects of event image (event inventiveness, event appropriateness, event adequacy) were proposed to influence students' satisfaction and revisit intentions. The research was conducted with 468 students who participated in the entrepreneurship event for two days. For the analyses, structural equation modeling technique was used. It was found that (i) the dimensions of event image (inventiveness, appropriateness, and adequacy) have an impact on students' satisfaction and (ii) students' satisfaction was a main driver of their revisit intention. Results, future researches and managerial implications were addressed..
\end{abstract}

Keywords: Event Marketing, Event Image, Event Satisfaction, Revisit Intention, University Events

JEL Codes: M10, M30, M31

\section{ETKINLIIK PAZARLAMASI İLE ÖĞRENCILERI ÇEKME: ÜNIVERSITELERDE GIRIŞiMCILIKK ETKINLIIĞINE YÖNELİK BİR ÖRNEK}

\section{ÖZ}

Etkinlik pazarlamasının artan önemine dayanarak, bu çalışmada, Türkiye'nin önde gelen üniversitelerinden birinin ev sahipliğini yaptlğı girişimcilik etkinliğinin üniversite öğrencilerine olan etkisi araştırılmıştır. Bu bağlamda, ögrencilerin memnuniyetlerini ve tekrar ziyaret etme niyetlerini, etkinlik imajinın ü̧ farklı unsurunun (etkinlik yaratıcıllğgl, etkinlik uygunluğu, etkinlik yeterliliği) etkili olduğu ileri sürülmüş̧ür. Araştırma iki gün boyunca girişimcilik etkinliğine katılan 468 ögrenciye uygulanmıştır. Analizler için, yapısal eşitlik modellemesi yöntemi kullanılmıştır. (I) Etkinlik imajı boyutlarının (yaratıcılı̆̆ın, uygunluğun ve yeterliliğin) ögrencilerin memnuniyeti üzerinde etkili olduğu ve (ii), tekrar ziyaret etme niyetlerinde, ögrrencilerin memnuniyetinin başlıca itici gü̧̧ olduğu saptanmıştır. Sonuçlar, gelecek araştırmalar ve yönetsel sonuçlar kapsaminda ele alınmıştır.

Anahtar Kelimeler: Etkinlik Pazarlaması, Etkinlik Imajı, Etkinlik Memnuniyeti, Tekrar ziyaret etme niyeti, Üniversite Etkinlikleri

JEL Kodları: M10, M30, M31

\footnotetext{
${ }^{1}$ Gebze Teknik Üniversitesi, Yrd. Doç. Dr. İşletmeBölümü_akocak@gtu.edu.tr

${ }^{2}$ Gebze Teknik Üniversitesi, Prof. Dr. İşletmeBölümü, tumer@gtu.edu.tr

${ }^{3}$ Arş.Gör., Gebze Teknik Üniversitesi, Arș. Gör. İșletme Bölümü ckoksal@gtu.edu.tr
}

http://orcid.org/0000-0002-1060-1593

http://orcid.org/0000-0002-0673-6866

http:/orcid.org/0000-0001-9139-0451 


\section{INTRODUCTION}

In response to the many changes and advances in technology and communication, event marketing is still an effectual instrument in the promotion mix (Tafesse, 2016; Vel and Sharma, 2010; Zarantonello and Schmitt, 2013). Event marketing has constituted itself as a nowadays innovative and non-classical way of communication that completes promotion mix (Nufer, 2016).Actually, Schreiber and Lenson (1994) highlight the event marketing concept as an important strategic tool of building long-term relations with customers. The different types of applications and potentials of events allow marketers to engage with target customer groups in terms of generating brand loyalty, sustainable relationships, positive wom etc. and make a bridge between brand, company and customer (Nufer, 2015).

Over the past years, marketing academicians pay attention to this novel subject (Gupta, 2003; Hoyle, 2002; Li et al., 2014). Especially they focus on the areas which are more related with event marketing such as experiential marketing, lifestyle, engagement marketing, sponsorship, public relations, relationship marketing, destination marketing etc. (Berry, 1983; Pan, 2007; Pine and Gilmore, 1999; Winkelmann et al, 2016; Vila-López and RodríguezMolina, 2013).

Event marketing has emerged as a new communication strategy involving the target audience as active participants at behavioral level. It provides a valuable way of constructing and strengthening relationships between brand and consumers, especially for service brands that do not provide any tangible output for the consumer (Duncan and Moriarty, 1998). Wohlfeil and Whelan (2004) define event marketing as interactive hyper realities concerning the brand where consumers are actively involved at behavioral level, possibly leading to an emotional link with the brand.

Although there have been many studies which are affinity with event marketing, McCole (2004) indicates the deficiency of the systematized body of knowledge about it. In similar way, Gupta (2003) underlines the need of scientific conceptual framework to utilize the impact of events. Even for the practitioners' side; which inherently contribute themselves to event marketing practice there has not been enough evidence of research in the marketing literature (Wood and Masterman, 2008). There have been few cases to show the challenge of events to guide practitioners in specific areas such as tourism and hospitality marketing (Williams, 2006), sports marketing and sponsorship (Wohlfeil and Whelan, 2005). 
Due to the lack of a scientifically proved conceptual model, a comprehensive framework is developed to show the underlying reasons of event satisfaction of customer and their revisit intention of annual events. The purposes of this study are (i) offering a comprehensive model to show the main reasons of revisiting annually organized events, (ii) finding out how firms generate successful event image with the sub-dimensions, namely, inventiveness, appropriateness and adequacy of event, and (iii) studying the effect of event image on event satisfaction.

\section{Literature Review}

The notion of event marketing origin is endured dates back to more than 100 years ago (Zarantonello and Schmitt, 2013). Companies or brands are hosting events to generate special and unique relationships with the target customers. By being participate to the event, customer may live experience with the companies or brands. Behrer and Larsson (1998) describe event marketing as a commitment to co-ordinate the communication around hosted event. And also event is a type of activity which brings together attendees in time and space to experience created atmosphere (Karlsson and Palmer, 2007). According to Kotler and Keller (2009:46) event marketing is "The promotion and marketing of a specific event such as a conference, seminar, exhibition, trade fair, artistic performances, company anniversaries and similar such events". Moreover, Nufer and Bühler (2015) indicate that event marketing is an experiencerelated and interactive promotion tool that helps companies to engage with target customer group with the specific designed events. On the other hand, companies have realized the importance of the interaction with consumers via events which may help them to transform their current customers into loyal ones and create new potential customers (Yu et al., 2015).

Event marketing concept has been evaluated varied ways; like discounts, free sample products, sale promotions, charity alignments, fun events or sponsorships that make customer of brand/company feel like not only attending a commercial but also gaining favor (Drengner et al., 2008). It is useful to emphasize that all activities provide customer experiences and are good drivers for senses in terms of increasing value. Because of these good and unique experiences consumers can be in an interaction with the company, product, brand etc. (Martensen et al., 2007). There are different categories of event marketing consisted of events like civic events, fairs and festivals, expositions, hallmark events, meetings and conferences, retail events, sports events and tourism (Karlsson and Palmer, 2007). Goldblatt (1998) defines meeting and conferences as "primarily educational seminars that provide networking opportunities both association members as well as corporate members". Reward programs, 
product launches, open days, product sampling, publicity events, road shows, press conferences, competitions/contests, exhibitions, corporate entertainment, charity fund raisers, trade shows, product visitor attractions, street events and pop-up shops can also be added to the forms of the event marketing (Zarantonello and Schmitt, 2013).

The characteristics of event marketing can be specified in the below (Tafesse, 2016):

- High audience involvement: Because event marketing tools are perceived less interfering or natural, consumers are more tend to be eager to interact and be involved in activities.

- Novelty: Novelty is one of the most important characteristics of the activities carried out in within the scope of event marketing. Consumers can engage in new ideas, concepts, activities, persons, brands etc. thanks to the event marketing applications.

- Experimental richness: Another substantial feature of event marketing activities is focus on customer experiences and stimulating their senses. Because of this characteristic event marketing can be evaluated as a tool for experiential marketing (Close et al., 2006).

- Transiency: Transiency feature includes spatial and temporal transiency. Thanks to this characteristic customers or attendees want to be a part of event and experience as soon as possible.

It can be said that event marketing activities are an important vehicle for creating experiences and connecting with attendees based on the above characteristics. Daniel et al. (2012) have listed the features that event marketing activities should carry as follows:

- Events have to be interactive and engaging.

- Some promotional gifts should be given to the attendees at the events.

- The program has to be flexible.

- Communication channels should be used concentrated. Lastly organization should emphasize facilities of the event (accessibility, parking free parking area, the menu, the program). 
On the other hand, marketing mix have an important role in event marketing. If marketers want to manage this communication tool successfully, they shouldn't ignore the relationship of the promotion mix (Eckerstein, 2003). A successful event should have the power to spread of positive sensation of pleasure among the attendees who are our stakeholder (Khotimah et al., 2016). In able to manage this sustainability, event owners listen to their target and feedbacks after the events/organization. Despite the growing importance of events, conferences, summits; there is limited empirical research investigating how companies improve (evaluate) - event consequences and the relationship between attendees of event satisfaction. Understanding how events image effect event satisfaction and how event satisfaction influe nce revisit intentions are very important for quality and sustainability or persistence for events (Close et al, 2006).

\section{Conceptual Framework and Hypotheses}

The relationships between the variables are summarized in Figure 1 which depicts the research model. In brief, the partially effect of sub-dimensions of event image (event inventiveness, event appropriateness and event adequacy) on event satisfaction and in terms of, the key constructs for generating event revisit intention have been investigated in a comprehensive integrative relationship framework.

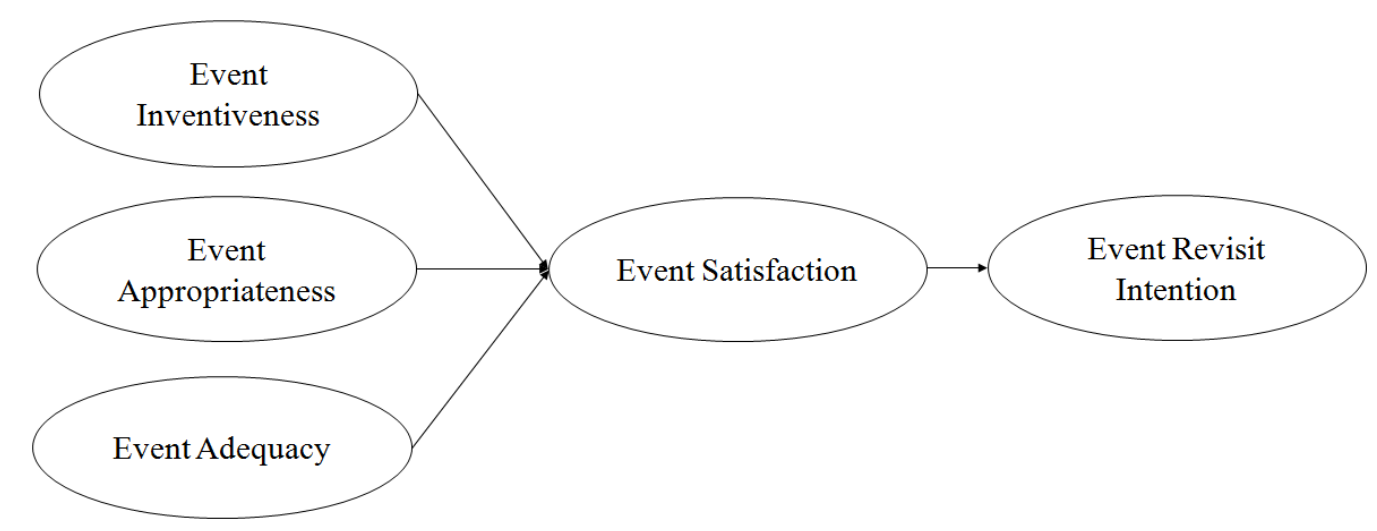

Figure 1: Research Model

\subsection{The Relationship between Event Image and Event Satisfaction}

In the literature, there are different descriptions about the image of the event. Gwinner (1997) defines event image, which includes event type, event characteristics and individual factors, as a particular market segment's overall subjective perceptions of the activity. On the other hand, Kaplanidou and Vogt (2007) define event image as "the mental representations active sport tourism participants have about the organization, environment, physical activity, 
socialization, fulfillment and emotional involvement with the event". Behrer and Larsson (1998) indicate communication, physical environment, products and services, ethic and social responsibility, engagement in social and local happenings and representatives from the company as the key factors of the event image. Also, event image concept has been investigated along with different constructs according to researchers' study field. For example, Kaplanidou and Vogt (2007) adapt event image to the sport image. Leischnig et al. (2011) has been defined event image as a construct, which consists of event inventiveness, event appropriateness and event adequacy. According to Leischnig et al. (2011) event inventiveness can be defined as attendees' perceptions of creativity and originality of the event; event appropriateness is related to attendees' perceptions about the degree to which the event is considered as a suitable tool for promotional purposes and event adequacy is the perception of how well an event fits with the companies' goals.

The studies about event marketing, the awareness of the activities and the sales and output effects are discussed more than other outputs. For example, Altunbas (2008) research about the event in the university has shown a direct positive effect of events on the brand awareness and product sales. On the other hand, it is revealed that event marketing's ability can affect positively perceptions and behavior (Sneath et al., 2005). Dregner et al. (2008) propose that event marketing applications can be used to influence the brand image. Although, the effect of events on direct sales cannot be measured, it is understood from the responses that shortterm effects (Sneath et al., 2005). Likewise, it is stated that the events are important for companies to create environments in which customers will contact more with the product and brand.

Although little attention has been paid to event image itself and its consequent variables, studies give support that event image has a positive effect on revisiting the event and recommending the event (Schreiber and Lenson, 1994). For example, studies conduct in the field of sports tourism has revealed the effect of the event image on behavioral intentions and satisfaction (Koo et al., 2014). On the other hand, studies have not fully addressed how event image at events contributes to an attendee's opinion of a sponsor's brand. Pope and Voges (2000) find a significant relationship an intention to purchase company's product and company's corporate image, a direct relationship between sponsorship awareness and purchase intention. Event marketing activities can integrate a wide kind of communication effects like building awareness, purchase, loyalty and partnership (Wood, 2009). The event 
image can bring along increased sales and also can strengthen the relationship between stakeholders and the organization (Eckerstein, 2003). Ponsonby and Boyle (2004) suggest a conceptual model that event characteristics and good or bad experience about the event cause to form their experiental value perception. Koo (2013) reports that positive image of an event positively influences satisfaction.

A review of the event image literature led to the following hypotheses:

H1: Event inventiveness has positive effect on event satisfaction.

$\mathrm{H} 2$ : Event appropriateness has positive effect on event satisfaction.

H3: Event adequacy has positive effect on event satisfaction.

\subsection{The Relationship Between Event Satisfaction and Event Revisit Intention}

Oliver (1980) defines satisfaction as a pleasure fulfillment via an overall evaluation of the service or product relative to the consumer's expectation and experience. Therefore, satisfaction can be appreciated as a function of expectation and experience (Koo et al., 2014). Briefly, satisfaction is as a fulfillment response about the consumer (Duman, 2003; Ozbek and Kulahlı, 2016).

The role of event satisfaction in event marketing context has been a primary subject of research in numerous studies (Drengner et al., 2008; Tsuji et al., 2007; Shonk and Chelladurai, 2008). Measuring future intentions of attendees is important for the continued success of an event. Revisit intention means that costumer will visit your company, event, organization etc. (Zeithaml et al., 1996). Ajzen (1991) suggest that future intentions (revisit, repurchase etc.) are directly relative to one's future behaviors. On the other hand literature shows some support for the effect of satisfaction on future behavioral intentions (Tsuji et al., 2007; Caro and Garcia, 2007; Duygun and Menteş, 2016). One's positive behavioral intentions come into existence from a high level of satisfaction. A satisfying experience at the event is an important predictor of attendance at future events (Clemes et al., 2011). Sufficient amount of marketing literature are supporting the relationship between customer satisfaction and revisit intention (Han et al., 2009; Jang and Feng, 2007; Kim et al., 2009; Um et al., 2006)

Based on these studies, it is proposed that;

H4: Event satisfaction has positive effect on revisit intentions. 


\section{Methodology}

The main objective of this study is to explain the effects of event inventiveness, event appropriateness and event adequacy on event satisfaction. In addition, the effect of event satisfaction over the revisit intentions has been analyzed.

\subsection{Sample and Data Collection}

The data were collected through a face-to-face questionnaire. Participants $(\mathrm{N}=468)$ were attendees of Gebze Technical University (GTU) Entrepreneurship Summit 2017 held in Kocaeli, Gebze. This is an annual and the main entrepreneurship event in its region, which is hosting by Government University. The questionnaire contained 20 questions, which were pretested and revised to clarify the meaning and remove all ambiguity. First part of the questionnaire included questions to measure demographic characteristics of the participants. Second part of the questionnaire included items to measure the main perceptions and evaluations (event image with the sub-dimension of event inventiveness, event appropriateness, event adequacy and event satisfaction) about the event and the last part of questionnaire included the items to measure intentions of revisit to the event.

Table 1 represents the demographic characteristics of the attendees. Participants are consisted of $47.22 \%$ male and $52.78 \%$ female. In terms of age, $86.54 \%$ of the respondents are between 15-30 years old and $13.46 \%$ are more than 31 years old. In terms of educational situation, $58.97 \%$ of the respondents are college students and $15.81 \%$ of the respondents are university students. $42.31 \%$ of the respondents were attended of the previous GTU Entrepreneurship Summits last year.

Table 1: Demographic Characteristics of Sample (n:468)

\begin{tabular}{cccc}
\hline Characteristics & & $\mathbf{N}$ & $\mathbf{\%}$ \\
\hline Gender & Female & 247 & 52.78 \\
& Male & 221 & 47.22 \\
\hline Age & $15-30$ & 405 & 86.54 \\
& above 31 & 63 & 13.46 \\
\hline \multirow{2}{*}{ Educational level } & High School & 115 & 24.57 \\
& Graduate & 3 & 0.64 \\
& Two-year degree & 276 & 58.97 \\
& College Degree & 74 & 15.81 \\
\hline Marital Status & Graduate School & 48 & 10.26 \\
& Married & 420 & 89.74 \\
\hline Previous Attendee & Unmarried & 198 & 42.31 \\
& Yes & 270 & 57.69 \\
\hline
\end{tabular}




\subsection{Measures}

All scales used a common five-point Likert scales with anchors $1=$ strongly disagree and $5=$ strongly agree were used. Event image was measured by using items adapted from the study of Leischnig et al. (2011). In this scale 3 items were used to event inventiveness; 3 items were used to event appropriateness and 3 items were used to measure event adequacy. Five items were used for the measurement of event satisfaction adapted by and Arnett et al.'s (2003) and Magi's (2003) scales. The revisit intention scale was adopted from Cronin et al.' (2000) study. Measurement items were presented in Table 2.

Table 2: Factor Loadings and Reliability Scores

\begin{tabular}{|c|c|c|c|c|c|}
\hline \multicolumn{2}{|c|}{ Construct } & $\begin{array}{l}\text { Standardized } \\
\text { loadings }\end{array}$ & $\begin{array}{l}\text { Cronbach's } \\
\text { alpha }\end{array}$ & CR & AVE \\
\hline \multicolumn{2}{|c|}{ Event Inventiveness (adapted from Leischnig et al. (2011)) } & \multirow[b]{2}{*}{$.79^{* *}$} & \multirow[t]{4}{*}{.860} & \multirow[t]{4}{*}{864} & \multirow[t]{4}{*}{.679} \\
\hline EI1 & $\begin{array}{l}\text { Generally, I found the sessions originally organized as part of } \\
\text { the Entrepreneurship Summit. }\end{array}$ & & & & \\
\hline EI2 & $\begin{array}{l}\text { Generally, the sessions organized as part of the } \\
\text { Entrepreneurship Summit gave meinnovative ideas. }\end{array}$ & $.86^{* *}$ & & & \\
\hline EI3 & $\begin{array}{l}\text { Generally, the sessions organized as part of the } \\
\text { Entrepreneurship Summit created creative ideas. }\end{array}$ & $.82^{* *}$ & & & \\
\hline \multicolumn{2}{|c|}{ Event Appropriateness (adapted from Leischnig et al. (2011)) } & & \multirow[t]{4}{*}{.776} & \multirow[t]{4}{*}{778} & \multirow[t]{4}{*}{.539} \\
\hline EA1 & $\begin{array}{l}\text { Generally, I found the speakers who were involved in the } \\
\text { Entrepreneurship Summit event credible. }\end{array}$ & $.70^{* *}$ & & & \\
\hline EA2 & $\begin{array}{l}\text { Generally, I found the issues discussed in the Entrepreneurship } \\
\text { Summit event to be applicable in real life. }\end{array}$ & $.72^{* *}$ & & & \\
\hline EA3 & $\begin{array}{l}\text { Generally, I found the topics discussed at the Entrepreneurial } \\
\text { Summit event to be appropriate for the purpose of the event. }\end{array}$ & $.78^{* *}$ & & & \\
\hline \multicolumn{2}{|c|}{$\frac{1}{\text { Event Adequacy (adapted from Leischnig et al. (2011)) }}$} & & \multirow[t]{4}{*}{.803} & \multirow[t]{4}{*}{808} & \multirow[t]{4}{*}{.585} \\
\hline EAD1 & $\begin{array}{l}\text { Generally, I found the speakers well-equipped in the field of } \\
\text { Entrepreneurship Summit event. }\end{array}$ & $.70^{* *}$ & & & \\
\hline EAD2 & $\begin{array}{l}\text { Generally, I believe that the Entrepreneurship Summit event } \\
\text { will lead to youth, entrepreneurship. }\end{array}$ & $.82^{* *}$ & & & \\
\hline EAD3 & $\begin{array}{l}\text { Generally, I found sessions that were held at the Entrepreneurial } \\
\text { Summit event to be useful for my personal development. }\end{array}$ & $.77^{* *}$ & & & \\
\hline \multicolumn{2}{|c|}{ Event Satisfaction (adapted from Arnett et al. (2003) and Magi (2003)) } & & \multirow[t]{4}{*}{.855} & \multirow[t]{4}{*}{861} & \multirow[t]{4}{*}{.674} \\
\hline SA1 & The Entrepreneurship Summit event met my expectations. & $.77^{* \pi}$ & & & \\
\hline SA2 & I am glad to be here at the Entrepreneurship Summit. & $.85^{* *}$ & & & \\
\hline SA3 & Overall, I am satisfied with the Entrepreneurial Summit event. & $.84^{* *}$ & & & \\
\hline \multicolumn{2}{|c|}{ Event Revisit Intention (adapted from Cronin et al. (2000)) } & & \multirow[t]{4}{*}{.898} & \multirow[t]{4}{*}{898} & \multirow[t]{4}{*}{.745} \\
\hline RI1 & $\begin{array}{l}\text { I plan to at tend the Entrepreneurial Summit event again next } \\
\text { year. }\end{array}$ & $.87^{* *}$ & & & \\
\hline RI2 & $\begin{array}{l}\text { I will recommend the Entrepreneurial Summit activity to my } \\
\text { friends. }\end{array}$ & $.85^{* *}$ & & & \\
\hline RI3 & $\begin{array}{l}\text { If I had a chance again, I came back to the Entrepreneurship } \\
\text { Summit again. }\end{array}$ & $.87^{* *}$ & & & \\
\hline
\end{tabular}

\subsection{Measure Assessments}

Structural equation modeling with Amos 16.0 and SPSS 21.0 have been used for testing the research model within the context of study. All factor loadings and reliability estimates for each construct are represented in Table 2. It is observed that composite reliability (CR) scores are ranged between $0.778-0.898$ and Cronbach's alpha estimates scores are ranged between 
0.776-0.898 which indicate that all measures are significantly reliable (Fornell and Larcker, 1981). Additionally, for convergent validity; the factor loadings of all constructs are large and significant. Discriminant validity of the constructs are determined by average variance extracted (AVE), and the AVE scores for all constructs exceed the minimum standard cut point of 0.50 (Fornell and Larcker, 1981). Additionally, the structural model shows a good fit to the data $(\chi 2: 234.92(\mathrm{df}=80), \chi 2 / \mathrm{df}=2.94$; Root mean squares error approximation $(\mathrm{RMSEA})=$ 0.06; comparative fit index $(\mathrm{CFI})=0.97$; goodness of fit index $(\mathrm{GFI})=0.94$; adjusted goodness of fit index $(\mathrm{AGFI})=0.91$ and incremental fit index $(\mathrm{IFI})=0.97)$ (Hair et. al, 1998). Table 3 presents the scale statistics including the means, standard deviations and correlations between all variables in the study. All correlation estimates are found significant and in the expected direction.

Table 3: Mean, Standard Deviations, and Pearson Correlation Coefficients

\begin{tabular}{llllllll}
\hline & Mean & SD & $\mathbf{1}$ & $\mathbf{2}$ & $\mathbf{3}$ & $\mathbf{4}$ & $\mathbf{5}$ \\
\hline 1-Event Inventiveness & 4.098 & .846 & 1 & & & & \\
2-Event Appropriateness & 4.293 & .723 & $.695^{(* *)}$ & 1 & & & \\
3-Event Adequacy & 4.258 & .747 & $.720^{(*)}$ & $.746^{(* *)}$ & 1 & & \\
4-Event Satisfaction & 4.262 & .797 & $.719^{(* *)}$ & $.705^{(* *)}$ & $.739^{(* *)}$ & 1 & \\
5-Revisit Intention & 4.327 & .839 & $.691^{(* *)}$ & $.671^{(* *)}$ & $.702^{(* *)}$ & $.822^{(* *)}$ & 1 \\
\hline
\end{tabular}

Note: ${ }^{* *} \mathrm{p}<0.001$

\subsection{Analyses and Results}

The proposed framework was tested in structural equation modeling (SEM) with AMOS 16.0. Fit statistics $(\chi 2=235,41 ; \mathrm{df}=83, \chi 2 / \mathrm{df}=2.84$; root mean squares error approximation $($ RMSEA $)=0.06$; comparative fit index $(\mathrm{CFI})=0.97$; goodness of fit index $(\mathrm{GFI})=0.94$; Tucker Lewis fit index $(\mathrm{TLI})=0.96$; normed fit index $(\mathrm{NFI})=0.95$; adjusted goodness of fit index $(\mathrm{AGFI})=0.91$ and incremental fit index $(\mathrm{IFI})=0.97)$ revealed that the model fits well to the observed data. Figure 2 shows the proposed model with the estimated path coefficients for the hypotheses suggested. 


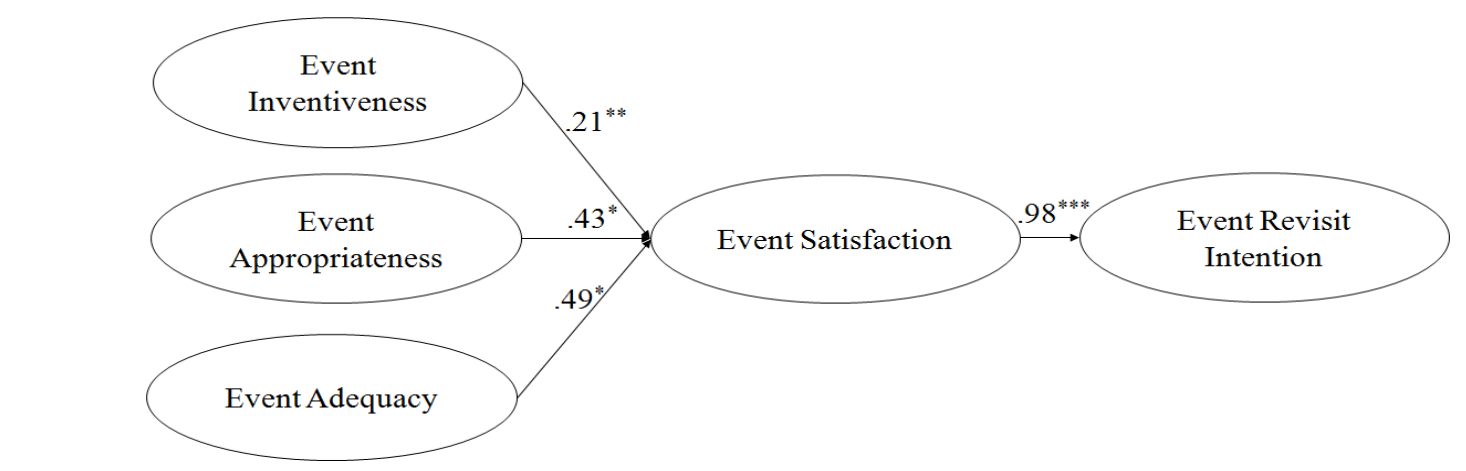

Note: ${ }^{*} \mathrm{p}<0.05 ;{ }^{* *} \mathrm{p}<0.01 ;{ }^{* * *} \mathrm{p}<0.001$

Figure 2: Structural Model with Parameter Estimates

Also, the estimated path coefficients are presented in Table 4. Consequently, all of the hypothesized effects are supported, $88 \%$ of the variance in revisit intention and $79 \%$ of the variance in event satisfaction are explained through the model.

Table 4: Structural Parameter Estimates

\begin{tabular}{|c|c|c|c|c|c|}
\hline Hypothesized path & $\begin{array}{l}\text { Standardized } \\
\text { estimates }(\beta)\end{array}$ & S.E & t value & p value & Results \\
\hline H1: Event Inventiveness $\rightarrow$ Event Satisfaction & 0.21 & .08 & $2.52^{* *}$ & 0.006 & Supported \\
\hline $\begin{array}{l}\text { H2:Event Appropriateness } \rightarrow \text { Event } \\
\text { Satisfaction }\end{array}$ & 0.43 & .23 & $1.90^{*}$ & 0.029 & Supported \\
\hline H3: Event Adequacy $\rightarrow$ Event Satisfaction & 0.49 & .25 & $1.99^{*}$ & 0.024 & Supported \\
\hline H4: Event Satisfaction $\rightarrow$ Revisit Intention & 0.98 & .05 & $19.11^{* * *}$ & 0.001 & Supported \\
\hline
\end{tabular}

Note: ${ }^{*} \mathrm{p}<0.05 ; * * \mathrm{p}<0.01 ; * * * \mathrm{p}<0.001$

Event satisfaction is significantly affected by event inventiveness $(\beta=0.21, t=2.52$, $\mathrm{p}<0.01)$, event appropriateness $(\beta=0.43, \mathrm{t}=1.90, \mathrm{p}<0.05)$ and event adequacy $(\beta=0.49, \mathrm{t}=1.99$, $\mathrm{p}<0.05$ ) supporting the hypotheses of $\mathrm{H} 1, \mathrm{H} 2, \mathrm{H} 3$. Consequently, this research supports the notion, that in particular events which have been evaluated as inventive, appropriate and adequate influence attendees' satisfaction positively. These findings are also support for, when the individual feels that, the event is originally organized and gives innovative and creative ideas, he/she finds the event inventive. If attendee finds the event appropriate with the purpose of the organization, he/she can be more satisfied. Moreover, attendee is more intended to join events like summits if the event is useful for his/her personal development and if the speakers are expert and well known in their field. Finally, $\mathrm{H} 4$ which proposed effect of the event satisfaction on revisit intensions to is supported $(\beta=0.98, \mathrm{t}=19.11, \mathrm{p}<0.001)$. These results confirm that the impact of attendees' satisfaction of events have an important effect on their future revisit intentions. 


\section{Discussion}

As the interests of the students on the entrepreneurship increase, universities begin to host entrepreneurship events in their structures. Universities prefer to host this type of important events because they want to create awareness about critical issues to their students and engage with students through this type of organizations (Sands et al., 2015). As mentioned before, researches about event marketing in this context is limited (Jiang and Schmader, 2014). Current study contributes to this deficient area by offering a comprehensive framework. This study attempts to address two main gaps in the literature on universities by presenting 1) the relationship between event image dimensions (event inventiveness, event appropriateness, and event adequacy) and event satisfaction and 2) event satisfaction effects on event revisit intentions. Drawing on relevant literature and a rich quantitative data, this study conceptualized the significant relationship between the sub-dimensions event image (event inventiveness, event appropriateness and event adequacy) and event satisfaction and the significant relationship between event satisfaction and revisit intention of event. In turn, these relations give some theoretical and managerial implications.

As mentioned in the related literature, extensive researches about event marketing are still in their infancy. While offering a comprehensive research model, this study conceptualizes event image with three dimensions, namely event inventiveness, event appropriateness, and event adequacy. In turn, it is proofed that each components of event image are important driver of event satisfaction. Then, with the line of past literature, this study indicates the importance of event satisfaction on revisit intention of event once again. The significant amount of variance, $88 \%$ of the variance in revisit intention and $79 \%$ of the variance in event satisfaction, is explained with the proposed model. The results show that event inventiveness, event appropriateness, and event adequacy are significant antecedents of attendees' satisfaction of events. This result is consistent with the findings from previous studies (Koo, 2013; Koo et al., 2014; Leischnig et al, 2011).

The role of event satisfaction in event marketing context has been a primary subject of research in numerous studies. Additionally, measuring future intentions of attendees is important for the prospective success of an event. The results of the current study confirm to previous studies that event satisfaction plays an important role to their intentions to revisit the event (Ajzen, 1991; Tsuji et al., 2007; Caro and Garcia, 2007; Clemes et al.,2011). 
Besides contribution to marketing field, this study underline the importance of the event satisfaction and event revisit intention drivers in young Turkish customer settings. The event, which consists innovative ideas in its structure, leverages participants' satisfaction. Moreover, entrepreneurship events are powerful organizations that delivers value from the business leaders to the participants. Especially in the growing countries like Turkey, this type of events help youth learn from the best practitioners, give chance for establishing new connections, discuss about their business plan and get some inspiration from the entrepreneurs or business people. Attending a talented summit that is appropriate for the purpose of the event, experienced entrepreneurs or practitioners can give participant chance to learn from their failure, which is an important outcome especially for the young people.

Furthermore, this study has some managerial implications especially for the ones who are organizing university events. First, it is very important to choose the speakers completely equipped in their field. Second, university students especially join that type of organizations for self-improvement so the event must leverage students demand in this view. Third, issues or topics should be applicable in real life and suitable for the purpose of the event. Last, the sessions should arouse innovative, creative ideas and feeling of novelty in the attendees that help event organizers to generate positive event image.

Future research needs to be extended to multi events in the same context; as an example; all universities entrepreneurship organizations. It would give chance to compare the strength and weakness of each events hosting by different organizations. By this means, it would be a great guidance for future events. Moreover, it is suggested that the association of these factors (event inventiveness, event appropriateness, event adequacy, event satisfaction and event revisit intention) is investigated in future studies within the different contexts. Also, further studies may focus on the role of this type of events on university' reputation, preference etc. Furthermore, future researches may study the moderating roles of demographic characteristic, such as gender, income, education and age, on the relationships between each dimensions of event image (event inventiveness, event appropriateness, event adequacy) and event satisfaction.

On the other hand, research has some limitations. The sample size was limited in a small scope. Study focused on individuals who participate to the summit in the context of this research. This study might be carried out in the future research is to understand perceptions and considerations of non-participants about events. 


\section{Conclusions and Recommendations}

The main objective of event marketing is creating a unique and good event image that transfer from an event to a company. The study presented above is an evidence for that thought. Companies can achieve this goal by hosting inventive, appropriate and adequate event. In the promotion mix, the usage of event marketing, that fits the event and companies' association, seems engaging the customer and the company and generating distinctive reputation for company.

In contrast with other communication mix tools such as advertising, direct marketing, personal selling etc.; aright-designed event marketing is by far effective and fit for the purpose of the company. 


\section{REFERENCES}

Ajzen, I. (1991). The theory of planned behavior. Organizational behavior and human decision processes, 50(2), $179-211$.

Altunbaş, H. (2008). Pazarlama İletişimi ve Etkinlik (Event) Pazarlamasi' müzik Eğlence Etkinliğinin Marka İletişimine Etkisi'. İstanbul Üniversitesi İletişim Fakültesi Dergisi|-Istanbul University Faculty of Communication Journal, (34), 23-36.

Arnett, Dennis B., Steve D. German, and Shelby D. Hunt (2003), "The Identity Salience Model of Relationship Marketing Success: The Case of Nonprofit Marketing,” JM, 67 (April), 89-105.

Behrer, M., Larsson, Å., \& Sandgren, J. O. (1998). Event marketing: att använda evenemang som strategisk resurs i marknadsföringen. IHM (Institutet för högre marknadsföringsutbildning).

Berry, L. L. (1983). Relationship marketing. American Marketing Association.

Caro, L. M., \& García, J. A. M. (2007). Cognitive-affective model of consumer satisfaction. An exploratory study within the framework of a sporting event. Journal of Business Research, 60(2), 108-114.

Clemes, M. D., Brush, G. J., \& Collins, M. J. (2011). Analysing the professional sport experience: A hierarchical approach. Sport Management Review, 14(4), 370-388.

Close, A. G., Finney, R. Z., Lacey, R. Z., \& Sneath, J. Z. (2006). Engaging the consumer through event marketing: Linking attendees with the sponsor, community, and brand. Journal of advertising research, 46(4), 420433.

Cronin, J. J., Brady, M. K., \& Hult, G. T. M. (2000). Assessing the effects of quality value, and customer satisfaction on consumer behavioral intentions in service environments. Journal of retailing, 76(2), 193218.

Daniel, M., Bogdan, G., \& Daniel, Z. (2012). The use of event marketing management strategies. Procedia-Social and Behavioral Sciences, 46, 5409-5413.

Drengner, J., Gaus, H., \& Jahn, S. (2008). Does flow influence the brand image in event marketing? Journal of Advertising Research, 48(1), 138-147.

Duman, T. (2003). Richard Oliver's Perspectives on Consumer Satisfaction and Consumer Value: A Theoretical Cross Examination. Dokuz Eylül Üniversitesi Sosyal Bilimler Enstitüsü Dergisi, 5(2), 45-56.

Duygun, A., \& Menteş, S. A. (2016). The Impacts of Corporate Reputation And Servıce Quality On Customer Satisfaction: A Research At Shopping Malls In Istanbul. Business \& Management Studies: An International Journal, 4(2).

Eckerstein, A. (2003). Evaluation of event marketing. rapport nr.: Masters Thesis, (2002). 
Fornell, C., \& Larcker, D. F. (1981). Structural equation models with unobservable variables and measurement error: Algebra and statistics. Journal of marketing research, 382-388.

Goldblatt, J. J. (1998). Special Events-Best Practice in Modern Event Management.

Gupta, S. (2003). Event marketing: Issues and challenges. IIMB Management Review, 15(2), 87-96.

Gwinner, K. (1997). A model of image creation and image transfer in event sponsorship. International marketing review, 14(3), 145-158.

Hair, J. F., Black, W. C., Babin, B. J., Anderson, R. E., \& Tatham, R. L. (1998). Multivariate data analysis (Vol. 5, No. 3, pp. 207-219). Upper Saddle River, NJ: Prentice hall.

Han, H., Back, K. J., \& Barrett, B. (2009). Influencing factors on restaurant customers' revisit intention: The roles of emotions and switching barriers. International Journal of Hospitality Management, 28(4), 563-572.

Hoyle, L. H. (2002). Event marketing: How to successfully promote events, festivals, conventions, and expositions (Vol. 2). John Wiley \& Sons.

Jang, S. S., \& Feng, R. (2007). Temporal destination revisit intention: The effects of novelty seeking and satisfaction. Tourism management, 28(2), 580-590.

Jiang, J., \& Schmader, S. W. (2014). Event management education and professionalism: The view from the trenches. Event Management, 18(1), 25-37.

Kaplanidou, K., \& Vogt, C. (2007). The interrelationship between sport event and destination image and sport tourists' behaviours. Journal of Sport \& Tourism, 12(3-4), 183-206.

Karlsson, C., \& Palmér, S. (2007). Event marketing: as a promotional tool for consumer brands. Unpublished Bachelor Thesis, Lulea University of Technology, Sweden.

Kim, T. T., Kim, W. G., \& Kim, H. B. (2009). The effects of perceived justice on recovery satisfaction, trust, word-of-mouth, and revisit intention in upscale hotels. Tourism Management, 30(1), 51-62.

Koo, S. K. (2013). The effect of destination image, event image, and satisfaction in determining behavioral intention: Recurring Small scale event (Doctoral dis sertation, University of Georgia).

Koo, S. K. S., Byon, K. K., \& Baker III, T. A. (2014). Integrating event image, satisfaction, and behavioral intention: Small-scale marathon event. Sport Marketing Quarterly, 23(3), 127.

Khotimah, K., Sari, D., \& Kaltum, U. (2016). Event Marketing and Experiential Marketing towards the Formation of Net Marketing Contribution Margin (NMCM) (Study at PT. Garuda Indonesia, TBK). Procedia-Social and Behavioral Sciences, 219, 431-439. 
Kotler, P. and Keller, K. (2009), Marketing Management, 13th ed., Prentice-Hall, Englewood Cliffs, NJ.

Leischnig, A., Schwertfeger, M., \& Geigenmüller, A. (2011). Shopping events, shopping enjoyment, and consumers' attitudes toward retail brands-An empirical examination. Journal of Retailing and Consumer Services, 18(3), 218-223.

Li, H., Song, W., \& Collins, R. (2014). Post-event visits as the sources of marketing strategy sustainability: a conceptual model approach. Journal of Business Economics and Management, 15(1), 74-95.

Magi, A.W. (2003). Share of wallet in retailing: The effects of customer satisfaction, loyalty cards and shopper characteristics. Journal of Retailing, 79(2), 97-106.

Martensen, A., Grønholdt, L., Bendtsen, L., \& Jensen, M. J. (2007). Application of a model for the effectiveness of event marketing. Journal of advertising research, 47(3), 283-301.

McCole, P. (2004). Refocusing marketing to reflect practice: The changing role of marketing for business. Marketing Intelligence \& Planning, 22(5), 531-539.

Nufer, G. (2015). Creating an image transfer through event marketing: principles, requirements and consequences. European Journal ofBusiness and Social Sciences, 3(12), 01-18.

Nufer, G. (2016). Event marketing and attitude changes. Journal of International Business Research and Marketing, 1(3), 44-49.

Nufer, G., \& Bühler, A. (2015). Event-Marketing in Sport und Kultur: Konzepte-Fallbeispiele-Trends.

Oliver, R. L. (1980). A cognitive model of the antecedents and consequences of satisfaction decisions. Journal of marketing research, 460-469.

Özbek, V., \& Külahlı, A. (2016). Do customers'involvement, satisfaction and loyalty levels differ according to gender? Business and Management Studies: An International Journal, 4(3).

Pan, B., MacLaurin, T., \& Crotts, J. C. (2007). Travel blogs and the implications for destination marketing. Journal of Travel Research, 46(1), 35-45.

Pine, B. J., \& Gilmore, J. H. (1999). The experience economy: work is theatre \& every business a stage. Harvard Business Press.

Ponsonby, S., \& Boyle, E. (2004). The'Value of Marketing'and'the Marketing of Value'in Contemporary TimesA Literature Review and Research Agenda. Journal of Marketing Management, 20(3-4), 343-361.

Pope, N. K., \& Voges, K. E. (2000). The impact of sport sponsorship activities, corporate image, and prior use on consumer purchase intention. Sport marketing quarterly, 9(2).

Sands, S., Oppewal, H., \& Beverland, M. (2015). How in-store educational and entertaining events influence shoppersatisfaction. Journal of Retailing and Consumer Services, 23, 9-20. 
Schreiber, A. L., \& Lenson, B. (1994). Lifestyle and event marketing: Building the new customer partnership. McGraw-Hill Companies.

Shonk, D. J., \& Chelladurai, P. (2008). Service quality, satisfaction, and intent to return in event sport tourism. Journal of sport management, 22(5), 587-602.

Sneath, J. Z., Finney, R. Z., \& Close, A. G. (2005). An IMC approach to event marketing: The effects of sponsorship and experience on customer attitudes. Journal of Advertising Research, 45(4), 373-381.

Tafesse, W. (2016). Conceptualization of brand experience in an event marketing context. Journal of Promotion Management, 22(1), 34-48.

Tsuji, Y., Bennett, G., \& Zhang, J. (2007). Consumer satisfaction with an action sports event. Sport Marketing Quarterly, 16(4), 199.

Um, S., Chon, K., \& Ro, Y. (2006). Antecedents of revisit intention. Annals of tourism research, 33(4), 11411158.

Vel, K. P., \& Sharma, R. (2010). Megamarketing an event using integrated marketing communications: the success story of TMH. Business strategy series, 11(6), 371-382.

Vila-López, N., \& Rodríguez-Molina, M. (2013). Event-brand transfer in an entertainment service: experiential marketing. Industrial Management \& Data Systems, 113(5), 712-731.

Williams, A. (2006). Tourism and hospitality marketing: fantasy, feeling and fun. International Journal of Contemporary Hospitality Management, 18(6), 482-495

Winkelmann, S., Dickenson, P., Souchon, A. L., Lee, N., \& Michaelidou, N. (2016). Event marketing and event sponsorship: can too much of a 'good'thing harm the brand?

Wohlfeil, M., \& Whelan, S. (2005). Event-marketing as innovative marketing communications: Reviewing the German experience. Journal of Customer behaviour,4(2), 181-207.

Wood, E. H. (2009). Evaluating event marketing: experience or outcome? Journal of Promotion Management, 15(1-2), 247-268.

Wood,E. H., \& Masterman, G. (2008), Event marketing: Measuring an experience. In 7th International Marketing Trends Congress, Venice.

Yu, Z., Zhang, D., Yu, Z., \& Yang, D. (2015). Participant selection for offline event marketing leveraging location based social networks. IEEE Transactions on Systems, Man, and Cybernetics: Systems, 45(6), 853-864.

Zarantonello, L., \& Schmitt, B. H. (2013) The impact of event marketing on brand equity, International Journal of Advertising, 32:2, 255-280, DOI: 10.2501/IJA-32-2-255-280. 
Zeithaml, V. A. (2000). Service quality, profitability, and the economic worth of customers: what we know and what we need to learn. Journal of the academy of marketing science, 28(1), 67-85. 